\title{
VII. On the vegetation of the first period of an ancient world, that is, from the first deposit of the transition series to the top of the coal-field; the magnesian limestone forming its upper limits: with remarks on the probability of its vegetable origin, \&c.
}

Henry Witham F.G.S.

To cite this article: Henry Witham F.G.S. (1830) VII. On the vegetation of the first period of an ancient world, that is, from the first deposit of the transition series to the top of the coal-field; the magnesian limestone forming its upper limits: with remarks on the probability of its vegetable origin, \&c. , Philosophical Magazine Series 2, 7:37, 23-31, DOI: 10.1080/14786443008675203

To link to this article: http://dx.doi.org/10.1080/14786443008675203

Published online: 14 Jul 2009.

Submit your article to this journal $₫$

Џll Article views: 2 
order to build one in the place of it of which they are unable to finish the roof*"

That Linnæus has in many parts of his works highly commended those who have distinguished themselves in investigating the natural relations of plants, is certain; but to suppose that by this he meant to approve of those who pretended to have formed a natural arrangement, is to attribute to him an opinion which he has disavowed in the most pointed terms. "A real botanist," says he, "will investigate the natural order of plants when it can be discovered ;" but, " he will not boast of having discovered a system perfectly conformable to the laws of naturet." And annong his diagnostics of pretended botanists he particularly includes that of "presuming that they are acquainted with a natural method $\neq . "$

[To be continued.]

VII. On the Vegetation of the First Period of an Ancicnt World, that is, from the First Diposit of the Transition Series to the Top of the Coal-field; the Magnesian Limestone forming its upper Limits: with Remarks on the Probability of its Vegetable Origin, \&.c. By Henry Witham, of Lartington, F.G.S. \&C. $\$$

$B^{1}$ EING firmly persuaded that the great objects of geology will be much advanced by a serious attention to the history of the vegetation of the different epochs, from the most remote period of organic creation down to the present day ; being most anxious to promote a spirit of inquiry in this country, as ardent as that of our continental neighbours, I have devoted a certain portion of my time to the examination of different coal-fields, to endeavour to corroborate by proof the assertions of that ingenious French naturalist who has lately favoured the world with many judicious remarks. upon this dark and difficult, but interesting branch of science.

* "Qui loco methodi naturalis disponunt plantas secundum ejus fragmenta, respuuntque artificialem, videntur mihi is similes, qui commodam et fornicatam domum evertunt, inque ejus locum reædificant aliam, sed tectum fornicis conficere non valent."

+ " Botanicus verus, ordinem naturalem, ubi patet indigitet."-Règn. régét. 27.

"Nec naturalissimam structuram oratorio sermone ebuccinat."-Phil. Bot. p. 294.

+ "Botanophili Fallaces-Methodum naturalem sibi notam crepant."Rign. Tígét. 27.

S Real before the Wernerian Society, Dec. $5 \mathrm{th}, 1829$; and communicated by the Author. 


\section{Mr. Witham on the Vegetation of the First Period of the World,}

I shall therefore now state to you the result of my limited investigation.

'To the ardour of M. Adolphe Brongniart, in the researches he has so suecessfully made in collecting materials for the physical history of the formations which compose the crust of our planet, every geologist must feel interested; as well as to Cuvier, Sternberg, Boué, Brown, D'Urville, and others, for their able and unremitting exertions in this dark field of early existence. It has been reserved for this eminent young naturalist to present to the public a classification so natural, and generally so clear, as greatly to facilitate the labours of those who interest themselves in such pursuits, and greatly to aid them in recording such particulars as may accidentally come under their immediate notice*.

Impressed with the importance of this subject, I first of all availed myself of the kindness of Mr. Dolphin, head-agent to Messrs. Hall and Co., who solicited me to explore a vein called Jefferies Rake, in the Derwent mines, near Blanchland, in the county of Durham. Having travelled up the adit about three quarters of a mile, we began to descend by the assistance of ladders. At the depth of about fifty-five fathoms below the surface, in a bed of sandstone nearly forty fathoms thick, we were gratified by a sight of some magnificent specimens of an ancient Flora, belonging to M. A. Brongniart's first period of vegetable creation. The two varieties appear to belong to his third class, "the Vascular Cryptogamia." The first were Stigmaria (Lycopodiaceæ); the second were fine specimens, of great circumference, of Sigillaria (Filices). Two of these last-named specimens, which were situated in the space cleared out to get at the lead ore, stand erect, and their roots are firmly embedded in a thin stratum of bituminous shale, much carbonized. I should think the height of one of these prodigions fern stumps may be about five feet, and its diameter probably exceeds two. The other, which has been kindly presented to me, may be seen in my museum, No. 14, Great King-street. It has, I understand, been the opinion of some gentlemen who have visited these ancient relics, that they have been washed into, and deposited in their present situation by some aqueous revolution.

To this conclusion I must object, for two reasons. First, because the roots are firmly embedded in the shale, as if they had remained undisturbed in their original earthy envelope; and Secondly, because you may discover in each cheek of the vein, other trunks of these members of this ancient Flora, in the solid rock, the position and the appearance of which are more

* See Phil. Mig. and Annals, vol. vi. p. 133. 
more consistent with the supposition that they grew on the spot where they were found. The confused heaping, fracturing and violence, which characterize diluvial action, are not seen here.

In proceeding towards the east, I received much valuable information from my intelligent friends $\mathrm{Mr}$. Buddle, an eminent coal viewer upon the rivers Tyne and Wear, and $\mathrm{Mr}$. Hutton of Newcastle, whose anxiety in pursuit of this branch of the science is so well known. In the great Newcastle coalfield, the fossil plants are generally in horizontal position, or parallel with the strata, in the greatest possible confusion; much broken, and the parts far separated. Indeed, the confusion is the most serious difficulty the observer has to contend with. It is difficult, however, to trace the operation of a current of water sweeping off the weaker vegetables, and depositing them where we now find them so beautifully preserved. Notwithstanding this, there are to be found in considerable abundance, in various positions, large and strong trunks of plants which appear to remain in their natural position, and which have been able to withstand the force of such torrent, if it can be proved that any such did exist. These vertical plants I have generally found to be the Sigillarice. The Saginaria, the Stigmarice, and Calamites (speaking generally), on the contrary, do not appear to have been sufficiently strong to have resisted any revolutionary influence. Below the main seam (which according to Mr. Forster's section of the strata is 150 yards below the surface), in a sandstone there are numbers of fossil plants standing erect, with their roots in a small seam of coal lying below. These stems, as you will perceive by the following diagram, are truncated, and lost in this seam, leaving room to believe they may have formed part of this combustible mass or bed.

High Main Seam.

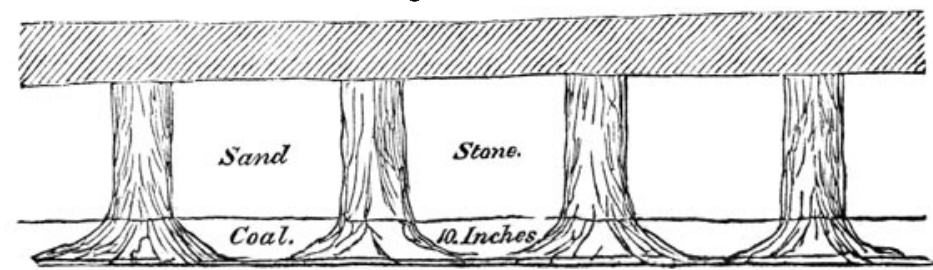

Again, in some of the seams, when the coal is worked away by the miners, the roof often falls. This is to a considerable degree owing to the number of vegetable impressions breaking the coherence of the stratum and bringing these fossils along

N.S. Vol. 7. No. 37. Jan. 1830. 


\section{$26 \mathrm{Mr}$.Witham on the Vegetation of the First Period of the World,}

with it. It must be observed that in almost every instance they are surrounded by a coating of very fine coal, of about half or three-quarters of an inch thick, having a polished surface, with very little attachment to the surrounding matter. This, I doubt not, is the cause of the fall ; the fossil dropping out sometimes as much as three feet in length, leaving a hole in the roof almost perfectly circular. Often it falls in these large pieces; but sometimes the nature of the shale of which its substance is composed, causes it to fall in portions of different thickness. It is to these falling pieces that the miner's expressive term Kettle Bottoms applies.

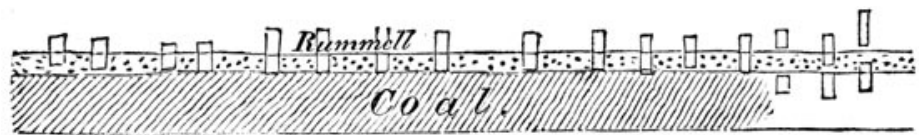

These fossil plants run from two to eight feet in circumference. The occurrence of numerous impressions which you may observe in the specimens of parts of different plants in the shale, forming the substance of these fossils, is to me, I must confess, very difficult of explanation. Some years ago a friend of mine found a kettle bottom at old Kenton colliery, eighteen inches in diameter, coated with fine coal, the substance of which was entirely mineral carbon or charcoal, with a mixture of earthy matter and pyrites. A portion of this specimen is in the collection of the Geological Society. It is much to be regretted that hitherto none of these interesting fossils have been followed into the strata. We do not know how far they extend, or to what height they are standing.

Again, in the coal districts of Scotland, amongst the troubles which affect the roofs of coal, there is one, of a very singular form, known by the name of Pot Bottom or Cauldron Bottom, and are from the size of one foot to five feet in diameter. One of these is represented in the annexed diagram.

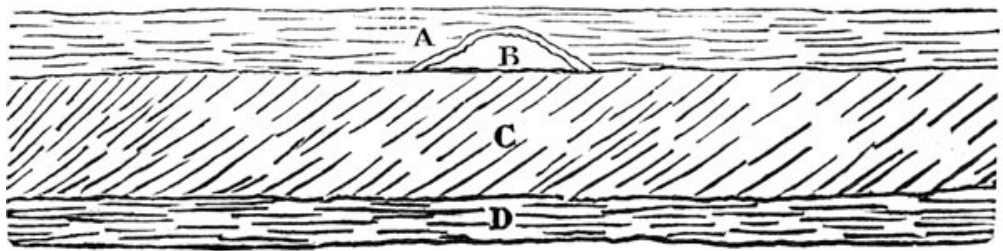

A. Roof of coal, argil with sand.

B. Pot or cauldron bottom.

C. Bituminous coal.

D. Pavement of coal. Fire clay. 
In working the bed of coal, the miner generally knows that he is approaching one of these by the coal becoming twisted and more difficult to work, and this continues till this trouble in the roof is passed. The general form is similar to that represented in the figure, when of course the mouth of the pot is always inverted, the sides of it are generally lined with coal from one-eighth of an inch to an inch in thickness, and the pot or cavity is filled up with stone of the argillaceous kind, or fire-clay, having generally less mixture of sand in it than is in the roof-stone around. The under surface of the stone which fills the pot is irregular and waving, not smooth like the roof adjoining.

Although the coal which lines the pot is connected with the main bed of coal, it is of a texture altogether different, having a bright appearance like jet, and it breaks into very minute cubical pieces; sometimes it has no bitumen in it, and is of the nature of glance coal. The sides of the pot are generally as smooth as glass, with small furrows or grooves in a vertical direction, so that there is very little tenacity between the sides of the pot and the stone which fills it up: this circumstance renders these troubles very dangerous, particularly when they are of a large size, as they fall without giving any warning. The peculiar singularity attending this trouble, is the twisted texture and alteration which are found in the bed of coal immediately under and adjoining it, without any mixture of the stone in it which fills up the pot.

There is sonetimes no lining of coal, and it generally happens that a piece of the stone, which fills up the pot, adheres to the upper part of the cavity, so that the trouble may go further up into the strata than is imagined. This trouble requires to be minutely investigated, and the pavement upon which the coal rests should be examined under the trouble, to ascertain if it is in any way altered in its structure, as is the case with the coal.

$\mathrm{I}$ am indebted to my much respected friend $\mathrm{Mr}$. Bald, civilengineer, for this latter information; and I am happy to say that it is his intention, at an early period, to devote his attention to these singularly curious objects.

Were further proof of the vegetable origin of coal wanting, the fact of finding impressions of the Saginarice in the solid coal, the thin layers of incoherent carbonaceous matter, having much of the silky aspect of charcoal, alternating with layers of good bituminous coal, and bearing the form of the Calamites most perfect, should go far to establish the vegetable origin of these combustible beds. 


\section{$28 \mathrm{Mr}$. Witham on the Vegetation of the First Period of the World,}

Having now troubled you with the few facts $I$ have been able to collect in the coal districts further south, to which I have added some remarks on the troubles of the Scotch basins,-I shall add some short observations on the neighbourhood of this city. Here again, I have been fortunate in obtaining many specimens of vascular cryptogamic plants, whose natural substances have been transubstantiated into the sedimentary deposits in which they were entombed, with the exception of their bark or outer coating, which is always much carbonized. The prevailing plants of this district, like those of the Newcastle field, appear to be the Sigillaria, the Saginarice, with a number of Calamites.

I beg leave here to mention, that in the neighbourhood of Burnt Island in Fifeshire, one of these vegetable fossils, the Stigmaria of Brongniart, the Lepidodendron of Sternberg, with strong impressions of its leaves, occurs in a limestone. This is a circumstance by no means of common occurrence. This limestone is devoid of any testaceous or coralline remains, and in appearance and composition, by analysis, varies little from the limestone of the Portland oolite. $\Lambda$ deposit of limestone also occurs at Hatton, near East Calder, containing terrestrial vegetable impressions.

I now take the opportunity of introducing an account of that fossil member of early vegetation, discovered in the year 1826, in the quarry of Craigleith.-The length of time which has been allowed to elapse without attempting to obtain the necessary information respecting this singular plant,-add to that, the peculiarity of its structure and composition,-has induced me to take much pains upon this point. I therefore laid a well cut transverse and also longitudinal section of this fossil tree before Mr. Hincks, botanical curator to the Philosophical Society of York. His opinion is, that it is a monocotyledonous plant; as a pithy substance fills up the interstices between the vessels, and that there has been no bark or concentric arrangement of layers. He also observes a striking resemblance to certainly monocotyledonous stems, which he has before examined. "On the whole," Mr. Hincks says, " having made the examination of this curious specimen submitted to me, with the greatest care, I can scarcely admit of a doubt upon the subject*."

* Since writing this paper I have received a kind communication from Mons. A. Brongniart, through Mr. Philips of York, to the following effect. "Please to inform Mr. Witham that l have received his specimen of the Craigleith fossil plant. It has much surprised and interested me. Having

The 
The internal structure, its singular colour when contrasted with the block of sandstone in which it was found, induced me to request my friend Mr. Nicol to analyse it. The following was the result:

60 per cent of carbonate of lime.

18 per cent of oxide of iron.

10 per cent of alumine.

9 per cent of carbonaceous matter.

The height of this gigantic plant was thirty-six feet; three feet diameter at its base, and lying in nearly horizontal position corresponding with the dip. No branches were found. This therefore, with a few others I could here mention, and which I trust will ere long be submitted to your consideration, form but trifling exceptions to the general distribution of early vegetation.

Thus in these great coal-fields (exclusive of the many varieties of plants found in the bituminous shale, which I am happy to say will shortly be submitted to the public, in a work intitled" "The Fossil Flora of Great Britain," by Mr. Lindley, Professor of Botany in the London University, and my friend Mr. Hutton of Newcastle) we find the opinion of M. A. Brongniart most completely verified; namely, that the vascular cryptogamic plants had a vast numerical proportion; and in fact, of 260 species discovered in this terrain or period, 220 belong to this class. "Should however," adds M. A. Brongniart, " more precise observations or new discoveries make known in the old formation, some plants of more than one of the classes which we have admitted, or even some species of one of the classes which have appeared to us to be wanting at this epoch, still the essential relation of these classes to each other would be but slightly modified. Thus it might be proved, that certain, yet little known genera of the coal formation, are true dicotyledonous plants. Yet it would not be the less certain, that the vascular cryptogamic plants were by much the most numerous vegetables, during the first period of vegetation." The same remarks he makes respecting the lias, and other formations. Thus whatever new discoveries may be made in the vegetables of this period, from the first deposit of the transition rocks to the top of the coal-field, yet the essential characters can be but slightly modified, and this period will always remain perfectly distinct.

The more gentlemen will therefore interest themselves in had so little time for examination, I cannot now give a final, but only a conditional cpinion. It is, that $I$ believe it to be a section of a monocotyledunous plant." 


\section{$30 \mathrm{Mr}$. Witham on the Vegetation of the First Periodof the World.}

promoting the examination of these ancient relics, the more likely are they to perceive the time fast approaching, when we shall be able with greater certainty to ascertain each deposit by the peculiarity of its vegetable fossils.

The essential character therefore of this first period of vegetation is proved to be the predominance of vascular cryptogamic plants; and we have here a most striking example of the great development which the species in question had attained in this first period of vegetable creation, when the two principal agents, heat and moisture, had evidently exerted an extraordinary influence.

Geologists have entertained, and do entertain, very different notions respecting the origin of coal.

It appears very probable, from the singular development of the vegetation of the first period, that these different combustible beds may have been deposited as a kind of peat of greater or less extent, formed from the remainder of vegetables, and on which other vegetables still grew. This opinion is, I should think, greatly confirmed by the description just given of the Newcastle coal-field. It appears also the more probable, as it is well known that many plants of the families composing this early vegetation, grow abundantly in localities of this kind. The Equisetum (Horsetail), the Osmunda regalis (Royal Moonwort), and the Lycopodium (Club Moss), are all indigenous in our peat soils. Again, we can scarcely doubt, that at this remote epoch our atmosphere had a very different composition from what it now has, and that its difference exerted a powerful influence upon the formation of those bodies of vegetable combustion. The comparison of the successive development of vegetables and animals is not one of the least remarkable parts of the study of these fossil organized bodies. This is beautifully expressed by M. A. Brongniart. He displays by a philosophical reasoning the effects produced by a supposed cause. He states with great perspicuity, why land animals did not exist at one period; why cold-blooded animals became more numerous at another period; and lastly, he gives cogent reasons for the appearance of animals of a more complicated structure, the mammiferæ and birds, in the fourth period.

M. A. Brongniart's reasonings upon this subject are so well epitomized by ProfessorJameson, in the Philosophical Journal for March 1829, that I should think it improper at present to enter into more minute details.

The study of this occult science truly opens a hidden field of animated beings and things, whose early call into existence 
Tables for the conversion into each other of Space and Time. 31 proves the omnipotence of the design. It brings into view a world little looked into or thought of, owing to the obscurity with which it was surrounded. It develops the early, the sublime, the successive works of the great Creator, which before were all supposed to be drowned and scattered about by the mighty burstings of a universal deluge. In other words, the contemplation of these stupendous operations is the true philosophy of the science of geology. If therefore the attention lately paid to the study of fossil conchology has been so highly instrumental in clearing up the many doubts respecting the different sedimentary formations ; if the works of Baron Cuvier and others, founded on the early observations of Werner, have afforded us so many interesting proofs of successive creations, from those of the early inhabitants of the deep up to the more complicated structure of the quadruped;-may we not expect equal pleasure and instruction from an application to the study of these ancient vegetable remains, which when once properly examined, will facilitate our knowledge of the forms, characters and qualities peculiar to each epoch, and of the degree of temperature and humidity which must have existed during each successive period.

December 6, 1829.

VIII. Compendious Tables for converting Time into Space, and Space into Time. By A Correspondent.

To the Editors of the Philosophical Magazine and Annals.

Gentlemen,

THE value of compendious and correct tables is well known to all practical men, and as among astronomers none are more frequently required than those for the conversion of time into space, and vice versâ, I send you two sets for the purpose, the arrangement of which seems preferable to any I have seen; the first may be fixed up in an Observatory; the latter consigned to a traveller's pocket.

I have the honour to be,

Yours, \&c. 